\title{
Analysis of the Nail Art Terminology Used in the Written Examination of National Technical Qualifications for Nail Technicians
}

Mi Ja Cho

Division of Beauty Industry, Joongbu University, Geumsan-gun, Chungcheongnam-do, Korea

Corresponding author: Mi Ja Cho, Division of Beauty Industry, Joongbu University, 201 Daehak-ro, Chubu-myeon, Geumsan-gun, Chungcheongnam-do 32713, Korea

Tel.: +82 417506636

Fax: +82 417506639

Email: 68cmj@joongbu.ac.kr

Received November 5, 2016

Revised February 6, 2017

Accepted February 16, 2017

Published March 30, 2017

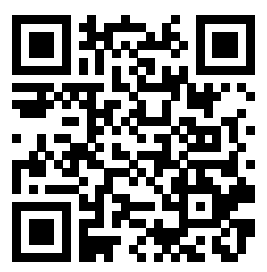

\begin{abstract}
Purpose: This study examined the improvement of the nail beauty terminology used in the national technical qualifications for nail technicians in order to improve the orthography of the terminology used in nail beauty-related training institutes and industries. The study analyzed loanwords in nail beauty terminology and identified problems in the introduction to nail beauty and nail beauty skill, which are major subjects in the written examination of national technical qualifications for nail technicians. Methods: In the written examination of national technical qualifications for nail technicians, loanwords in the nail beauty terminology used in the introduction to nail beauty and nail beauty skill were analyzed. The cases including different Korean orthography of terminology with the same meaning and different spacing in Korean terminology with the same meaning was analyzed. Also, nail beauty terminology was compared and analyzed between the written examination for nail technicians and material for editing of textbooks (III). Results: This study extracted 272 terminologies. Of them, 63 had the same meaning but different Korean orthography and 18 had the same meaning but different spacing in Korean. Eighteen terminologies extracted from the written examination were relevant to material for editing of textbooks (III). Conclusion: Further research should be conducted on nail beauty terminology used in the written examination subjects of national technical qualifications for nail technicians to analyze different orthography of terminology with the same meaning, spacing, and loanword orthography in various ways for the systematic standardization of terminology.
\end{abstract}

Keywords: Nail technicians, National technical qualifications, Nail beauty, Terminology, Written examination

\section{Introduction}

미용은 신체를 사회학적으로나 문화적, 그리고 심미적으로 아름 답게 표현하는 것을 의미하며, 과학과 기술을 바탕으로 실용 학문 으로서의 발전을 거듭하고 있다. 미용업이란 손님의 얼굴 - 머리 피부 등을 손질하여 손님의 외모를 아름답게 꾸미는 영업을 말하 며, 미용업에 종사하는 자는 반드시 국가기술자격 미용사(일반), 미 용사(피부), 미용사(네일), 미용사(메이크업) 자격증을 취득하여 면 허증을 발급받아야 한다.

2016년 국가기술자격통계연보의 자료에 의하면 우리나라의 국 가기술자격은 2015년 기준으로 총 526종목이며, 2014년 589,171
명, 2015년 647,670 명의 국가기술자격 취득자가 배출되었다. 이 중 미용사(일반)은 14,221명(2014년), 12,945명(2015년)이 국가기 술자격을 취득하였고, 미용사(피부)는 14,147명(2014년), 13,752명 (2015년)이 국가기술자격을 취득하였으며, 미용사(네일)은 20,236 명(2015년)이 국가기술자격을 취득하였다(Human Resources Development Service of Korea, 2016).

국가기술자격법 제 2 조 제1항에 따르면 '국가기술자격'은 자격기 본법에 따른 국가자격 중 산업과 관련이 있는 기술·기능 및 서비 스 분야의 자격을 말하며, 국가기술자격제도는 국가가 산업현장에 서 직무수행에 필요한 지식·기술의 습득 정도를 평가 · 인정하는 제도로, 제1조에 국가기술자격제도를 효율적으로 운영하여 산업현 
장의 수요에 적합한 자격제도를 확립함으로써 기술인력의 직업능 력을 개발하고, 기술인력의 사회적 지위 향상과 국가의 경제발전에 이바지함을 목적으로 한다.

미용사는 국민의 건강과 직결되어 있는 공중위생분야에서 미용을 수행하는 사람으로서, 국가의 산업구조가 제조업에서 서비스업 중심 으로 전환되는 차원에서 수요가 증대하고 있다. 분야별로 세분화 및 전 문화되고 있는 세계적인 추세에 발맞추어, 미용의 업무 중 헤어, 피부, 네일, 메이크업의 업무를 수행할 수 있는 미용분야 전문인력을 양성하 여 국민의 보건과 건강을 보호하기 위하여 자격제도를 제정하였다.

현재 미용사 국가기술자격제도는 2007년 보건복지부에서 공중 위생관리법을 시행규칙으로 개정함으로써, 미용사(일반) 국가기술 자격과 미용사(피부) 국가기술자격을 신설하여 시행령을 실시하였 고, 2014년 7월에는 미용사(네일) 국가기술자격을 신설하여 시행령 을 실시하였으며, 2016년 7월에는 미용사(메이크업) 국가기술자격 을 신설하여 시행령을 실시하고 있다.

이에 미용산업이 요구하는 우수한 미용인을 배출하기 위해서는 미용관련 기능사의 자격증이 실질적으로 국가경제기반의 발전과 개 인의 지식향상에 도움이 되는지는 고찰해야 할 부분이며, 국가기술 자격 미용사(일반), 미용사(피부), 미용사(네일), 미용사(메이크업)의 자격내용 및 방법 등의 지속적인 연구가 필요하다고 사료된다.

Oh (2011)는 미용업은 신체에 물리적 - 화학적인 작용을 가함으 로써 외모의 변화를 꾀하여 내면과 정신적 변화 등을 동반하므로, 미용업을 하기 위해서는 청결한 위생관리 규정과 엄격한 기준과 자 격을 기초로 한 국가기술자격 취득을 통해 전문성을 갖춰야 할 필 요가 있다고 하였다.

국가기술자격 중 미용사(네일)은 국가기술법 시행규칙 일부개정 령으로 2014년도 6월 12 일 고용노동부령 제101호로 개정되어, 국 가기술자격법 시행령 제 15 조(검정의 시행 등) 및 동법 시행규칙 제 12 조(수시검정)의 규정에 따라 2014년 미용사(네일) 검정 시행계획 을 공고하였으며, 2014년 7월 1일부터 국가기술자격법에 의한 미 용사(네일) 자격이 시행되었다.

이에 미용사(네일)은 2014년 11월 16일 국가기술자격 필기시험이 시행되어 33,675 명이 응시하고 그 중 12,596 명이 합격하여 $37.4 \%$ 의 합격률을 나타냈다.

국가기술자격명은 미용사(네일)로 영문명은 nail technician이며, 미용사(네일)의 관련부처는 보건복지부이고 시행기관은 한국산업 인력공단이다.

미용사(네일) 필기시험은 네일 미용에 관한 숙련기능을 가지고 현장업무를 수행할 수 있는 능력을 가진 전문기능인력을 양성하고 자 자격제도를 제정하고, 수행직무는 손톱 - 발톱을 건강하고 아름 답게 하기 위하여 적절한 관리법과 기기 및 제품을 사용하여 네일 미용 업무를 수행하는 것이다. 미용사(네일)의 필기시험 출제기준 의 직무분야는 ‘위생'이고, 검정방법은 객관식 4 지 택일 형, 합격기 준은 100 점 만점에 60 점 이상일 경우 합격이며, 문제수는 60 문항,
소요시간은 $1 \mathrm{~h}$ 으로 응시자격에는 제한이 없다(Lee et al., 2015).

미용사(네일)의 필기과목명은 네일 개론, 공중위생관리학, 네일 미용기술 등으로 한국 산업인력공단에서는 미용사(네일) 필기시험 출제기준 세부사항을 2014년 10월 1일부터 2019년 12월 31일까지 시행한다고 하였는데, 2016년에 2016년 미용사(네일) 필기시험 변 경된 출제기준 세부사항을 2016년 7월 1일부터 2020년 12월 31일 까지 시행한다고 발표하였다.

국가기술자격 미용사(네일) 필기시험은 문제은행식 출제방법으로 노출되는 문제가 많아짐에 따라 큰 어려움 없이 합격할 수 있으나, 사용되는 많은 네일 미용 전문 용어의 올바른 사용과 표기에 대한 이 해가 부족하고 이에 대한 연구 또한 미비한 실정이다. 또한, 네일 미 용에 관한 용어들은 미국 등 외국에서 유입되어 점차 외래어화 또는 외국어를 발음하는 대로 한글화하여 그대로 사용하고 있다. 현재 의 학계에서도 외래어를 순 우리말로 바꿔가고 있는 추세로, Kim et al. (2010)은 이러한 전문 용어들은 일반인들까지도 이해하기 쉬운 우리 말로 바꾸고 외래어의 한글표기 문제도 학문의 발전과 교육을 위해 서 시급하다고 하였다.

기술변화가 빠른 미용산업은 기존의 단순기능 중심에서 탈피하여 고기능 및 다기능 인력에 대한 수요가 점진적으로 증가하고 있는 실 정으로(Cho et al., 1999), 미용사(네일)은 자격의 내용이 산업현장의 직무와 괴리되지 않고 기술변화와 공생하여야 하며, 자격증 소지자 는 산업현장에서 요구하는 실무능력을 유지하고 향상시켜야 한다.

이와 연관된 미용 관련 선행연구를 살펴보면 용어분석 및 용 어표기, 교과서에 대한 분석, 국가기술자격에 대한 연구로, Cha \& Ahn (2011), Cho et al. (1999), Choi \& Kim (2010), Huh et al. (2013), Jeong (2012), Lee \& Yoon (2010), Lee et al. (2012), Lee et al. (2001), Lim et al. (2013), Moon et al. (2013) 등이 있으나, 전문적인 미용의 학습자를 위해서 정확한 용어 사용이 중요하지만 실제 국가기술자격 취득을 위한 미용사 필기시험의 전문 용어 분 석에 대한 연구는 미흡한 실정으로, 네일 미용의 전문화된 교육을 위해서는 국가기술자격 미용사(네일) 필기시험 전문 용어의 분석과 연구가 필요하다고 사료된다.

따라서 본 연구자는 매회 시행되는 국가기술자격 미용사(네일) 필기시험 주요항목 중 네일 미용과 관련된 네일 개론과 네일 미용 기술에서 외래어로 된 네일 미용 전문 용어를 분석하고 문제점을 파악하여 네일 미용 관련 전문교육기관과 산업현장에서의 원활한 용어표기로, 미용사(네일) 국가기술자격 전문 용어의 개선방향을 모색하고자 한다.

\section{Methods}

\section{1. 연구대상}

미용사(네일) 국가기술자격 필기시험은 고용노동부 산하 한국 
산업인력공단 주관 하에 2014년 11월 16일에 처음으로 시행되었 다. 2015년 미용사(네일) 국가기술자격 필기시험 일정은 제 1 회 미 용사(네일)은 필기시험 제외로 응시가 없었고, 제 2 회는 4 월 4 일, 제 3 회는 산업수요 맞춤형 고등학교 및 특성화 고등학교 필기시 험 면제자 검정으로 일반인은 응시 불가, 제 4 회는 7 월 19 일, 제 5 회는 10월 10일에 시행되었다. 2016 미용사(네일) 국가기술자격 필기시험 일정으로는 제 1 회 1 월 24 일, 제 2 회 4 월 2 일, 제 3 회는 산업수요 맞춤형 고등학교 및 특성화 고등학교 필기시험 면제자 검정으로 일반인은 응시 불가, 제 4 회는 7 월 10 일, 제 5 회부터는 $\mathrm{CBT}$ 접수로 기존방식과 다르게 변경되었다.

본 연구에서는 미용사(네일) 필기시험을 대상으로 분석하였으 나 국내외의 선행 연구 및 관련 논문은 거의 없는 실정이고, 2016 년 9월부터는 CBT접수로 변경됨으로써, 2014년도에 진행된 필 기 1회, 2015년 2회, 4회, 5회, 2016년 1회, 2회까지의 회별 미용 사(네일) 필기시험 문제에 대해 연구하였으며, 매년 3회 필기시험 은 산업수요 맞춤형 고등학교 및 특성화 고등학교 필기시험 면제
로 일반인에게는 시행하지 않아서 제외하였다.

\section{2. 연구방법}

본 연구는 미용사(네일) 국가기술자격 필기시험 주요항목 "네일 개론, 피부학, 공중위생관리학, 화장품학, 네일 미용기술' 중 네일 미용과 관련된 네일 개론과 네일 미용기술에서 외래어로 된 네일 전문 용어를 분석하고, 미용사(네일) 필기시험 문제에서 같은 의 미의 용어가 한글 표기가 다르게 된 경우, 미용사(네일) 필기시험 문제에서 같은 의미의 용어가 한글 표기 띄어쓰기가 다르게 된 경우를 분석하였다. 그리고 이와 같은 미용사(네일) 필기시험에 서 나타난 용어와 교과서 편수 자료(III) 응용 과학 편, VII. 가사 . 실업(Ministry of Education, 2011)에서 해당되는 네일 미용 전문 용어를 분석하였다.

\section{Table 1. Analysis of nail beauty terminology in the written examination for nail technicians}

\begin{tabular}{|c|c|}
\hline \multicolumn{2}{|r|}{ Nail art terminology } \\
\hline$\neg(13)$ & $\begin{array}{l}\text { 거스러미 네일(hang nail), 고랑 파진 네일, 고랑 파진 손톱(훠로우 네일), 그리트(grit), 계란껍질 네일(onychomalacia), 교조증(오니코파지), } \\
\text { 교조증(오니코파지, onychophagy), 그라데이션, 글루, 글루드라이, 글루 드라이, 글리세린, 과산화수소 }\end{array}$ \\
\hline$\llcorner(46)$ & $\begin{array}{l}\text { 나일론, 니버스(모반점), 니트로셀룰로즈, 니트로셀룰로오즈, 니퍼, 네일, 네일 그루브(조구), 네일 그루브(nail groove), 네일 리무버, 네일 매트릭스, } \\
\text { 네일 매트릭스(nail matrix), 네일루트, 네일 루트(조근), 네일몰드, 네일바디, 네일 바디, 네일 바디(조체), 네일블리치, 네일베드, 네일 베드, 네일 } \\
\text { 베드(조상), 네일아티스트, 네일에나멜, 네일 에나멜(nail enamel), 네일 에나멜 시너, 네일 종이 폼, 네일샵, 네일 샵(shop), 네일숍, 네일 큐티클, } \\
\text { 네일 큐티클(nail cuticle), 네일 클리퍼, 네일 팁, 네일팁(nail tip), 네일 팁 오버레이, 네일 파일, 네일 프리에지(nail free edge), 네일 폴드(조주름), } \\
\text { 네일 폴리시, 네일 플레이트, 네일 플레이트(조판), 네일 플레이트(nail plate), 네일 폼, 내로우 팁, 네일 컬러(nail color), 네일 컬러링 }\end{array}$ \\
\hline ᄃ (3) & 디스펜서, 디펜디쉬, 드릴머신 \\
\hline ᄅ (11) & $\begin{array}{l}\text { 라이트 큐어드 젤(light cured gel), 라운드 패드, 라운드 쉐입, 라운드형, 리프팅, 리프팅(lifting), 루눌라, 루눌라(반월), 루눌라(lunula), 리퀴드, 레귤러 } \\
\text { 메니큐어(regular manicure) }\end{array}$ \\
\hline$\square(11)$ & 마누스, 마누스(manus), 마사지, 모노머, 모반점(니버스), 매니큐어, 매니큐어(manicure), 매트릭스, 매트릭스(조모), 모양(shape), 몰드 \\
\hline$\forall(7)$ & 비드, 반월(루눌라), 박테리아, 베이스코트, 베이스 코트, 브러시, 변색된 손톱(discolored nails) \\
\hline$\curlywedge(17)$ & $\begin{array}{l}\text { 사이드 윌, 시스테인, 스마일라인, 스마일 라인, 스트레스 포인트, 스퀘어 모양, 스퀘어 쉐입, 스퀘어형, 스컬프쳐 네일, 실크, 슬림 라인(slim line), } \\
\text { 습식매니큐어, 샌딩블럭, 샌딩 파일, 샵, 쉐입, 소프트 젤(soft gel) }\end{array}$ \\
\hline$\circ(57)$ & $\begin{array}{l}\text { 아미노산, 아몬드형, 아몬드형 쉐입, 아몬드형 네일, 아세테이트, 아세톤, 아크릴, 아크릴 리퀴드, 아크릴 오버레이, 아크ㄹㅣㅣ파우더, 아크릭 파우더, } \\
\text { 아크릴릭, 아크릴릭(acrylic), 아크릴릭 네일, 아크릴릭 브러시, 아크릴릭 스캅쳐, 아크릴릭 파우더, 아크릴 프렌치 스컬프처, 아크릴릭 브러시, } \\
\text { 아크릴릭 폼지, 에칭, 에칭(etching), 에포니키움, 에포니키움(조상피), 오니키아(조갑염), 오니코렉시스(조갑종렬증), 오니코렉시스, 오니코아트로피, } \\
\text { 오니코크립토시스, 오니코파이마, 오렌지우드스틱, 오렌지 우드스틱, 오발형, 오버레이, 오벌 쉐입, 오일, 에나멜, 에그쉘 네일(조갑연화증), 에머리 보드, } \\
\text { 위축된 네일(onychatrophia), 알코올, 인조네일, 인조 네일, 인조팁, 인조 팁, 엑티베이터, 액티베이터, 원톤 스캅춰, 원톤 스컬프쳐, 엘로우 라인, 웰, } \\
\text { 유색 폴리시, 유색 네일 폴리시, 일반 네일 폴리시, 아래로 향한 손톱(claw nail), 위로 솟아 오른 손톱(spoon nail), 올리고머 }\end{array}$ \\
\hline 丆 (17) & $\begin{array}{l}\text { 자연 네일, 자유연(프리에지), 조구(네일 그루브), 조근(네일 루트), 조모(매트릭스), 조상(네일 베드), 조상연(페리오니키움), 조체(네일 바디), 젤, 젤 글루, } \\
\text { 젤 네일, 젤 큐러링, 조갑 비대증(오니콕시스), 조갑박리증(오니코리시스), 조갑위축증(오니기트로피아), 조갑 익상편(테리지움), 조갑 종렬증(오니코렉시스) }\end{array}$ \\
\hline э (17) & 커브 팁, 크레졸, 큐라, 큐라(cure), 큐어링, 큐티클, 큐티클 니퍼, 큐티클 오일, 컨벡스, 컨케이브, 콘커터, 클리퍼, 컬러, 컬러링, 케라틴, 칼슘, 케어 \\
\hline$E(12)$ & 투톤 아크릴 스컬프처, 토우세퍼레이터, 토우 세퍼레이터, 탑 젤, 탑코트, 탑 코트, 톱코트, 탑 코트(top coat), 투톤 스캅춰, 팁, 팁 위드 랩, 톨루엔 \\
\hline II (38) & $\begin{array}{l}\text { 파라핀 메니큐어(paraffin manicure), 파란 네일(onychocyanosis), 파일, 파일링, 파우더, 포인트형, 푸셔, 프라이머, 프리프라이머, 프리에지, 프리엣지, } \\
\text { 프리에지(자유연), 프리에지(free edge), 프렌치, 프렌치 매니큐어(French manicure), 프렌치 스캅춰, 프렌치 스컬프처, 프렌치 스컬프처(French } \\
\text { sculpture), 프렌치 컬러링, 프리 월, 포르말린, 플라스틱, 팔리시, 폴리시, 폴리쉬, 핀칭, 핀칭(pinching), 풀코트(full coat), 풀 웰(full well), 핑거볼, 폴리시 } \\
\text { 리무버, 패디아트, 페디파일, 페디큐어, 패디큐어(pedicure), 페디큐어 컬러링, 핀셋, 표피조막(테리지움) }\end{array}$ \\
\hline के (13) & $\begin{array}{l}\text { 하드 젤(hard gel), 하조피(하이포니키움), 하프 웰(half well), 하이포니키움, 하이포니키움(하조피), 하이포인트, 하이 포인트, 히팅, 화이트 파우더, 핫오일 } \\
\text { 메니큐어(hot oil manicure), 행네일, 헤나, 헤나(henna) }\end{array}$ \\
\hline$A-Z(7)$ & $\mathrm{C}$ 커브, $\mathrm{pH}$ 밸런스, $\mathrm{UV}$ 젤, $\mathrm{UV}$ 젤네일, UV 젤 네일, UV-젤 네일, UV 젤 팁 오버레이 \\
\hline $1-100(3)$ & 100그릿 네일 파일, 20볼륨 과산화수소, $100 \%$ 아세톤 \\
\hline
\end{tabular}




\section{Results and Discussion}

\section{1. 미용사(네일) 필기시험 문제의 네일 미용 전문 용어 분석}

전문 용어는 특정한 전문분야에서 주로 사용되는 학술 용어나 기술 용어 등을 의미한다. 2014년도에 진행된 필기 1회, 2015년 2 회, 4회, 5회, 2016년 1회, 2회까지의 회별 미용사(네일) 필기시험 문제에서 네일 미용과 관련된 네일 개론과 네일 미용기술 중 외래
어로 된 네일 미용 전문 용어를 분석한 결과 272 개의 용어가 추출 되었다. 추출된 네일 미용 전문 용어를 자음, 알파벳, 숫자 순으로 Table 1과 같이 정리하였다.

\section{2. 미용사(네일) 필기시험 문제에서 같은 의미의 용어가 한글 표기가 다르게 된 경우}

2014년도에 진행된 1회, 2015년 2회, 4회, 5회, 2016년 1회, 2회

Table 2. Terminology with the same meaning but different Korean orthography in the written examination for nail technicians

\begin{tabular}{|c|c|c|c|}
\hline \multicolumn{4}{|c|}{ Written examination terminology } \\
\hline 1 & 거스러미 네일(hang nail)=행네일 & 33 & 브러시=아크릴릭 브러시 \\
\hline 2 & 고랑 파진 네일=고랑 파진 손톱(휘로우 네일) & 34 & 스퀘어 모양=스퀘어 쉐입=스퀘어형 \\
\hline 3 & 그리트(grit)=그릿 & 35 & 스마일 라인=스마일라인=엘로우 라인 \\
\hline 4 & 교조증(오니코파지)=교조증(오니코파지, onychophagy) & 36 & $\begin{array}{l}\text { 스컬프처 네일=아크릴 }=\text { 아크릴릭 }=\text { 아크릴릭(acrylic)=아크릴릭 } \\
\text { 네일=아크릴릭 스캅쳐 }=\text { 원톤 스캅춰=원돈 스컬프쳐 }\end{array}$ \\
\hline 5 & 니트로셀룰로오즈=니트로셀룰로즈 & 37 & 샌딩블럭=샌딩 파일 \\
\hline 6 & 니퍼=큐티클 니퍼 & 38 & 아몬드형=아몬드형 네일=아몬드형 쉐입=포인트형 \\
\hline 7 & 니버스(모반점)=모반점(니버스) & 39 & 아세톤=100\% 아세톤 \\
\hline 8 & 네일=자연네일=자연 네일 & 40 & 아크릴파우더=아크릴 파우더=아크릴릭 파우더=파우더 \\
\hline 9 & 네일 그루브(조구)=네일 그루브(nail groove)=조구(네일 그루브) & 41 & $\begin{array}{l}\text { 아크릴 프렌치 스컬프처=투톤 아크릴 스컬프처=투톤 스캅춰=프렌치 } \\
\text { 스캅춰=프렌치 스컬프처=프렌치 스컬프처(French sculpture) }\end{array}$ \\
\hline 10 & 네일 리무버=폴리쉬 리무버 & 42 & 에칭=에칭(etching) \\
\hline 11 & 네일루트=네일 루트(조근)=조근(네일 루트) & 43 & 에포니키움=에포니키움(조상피) \\
\hline 12 & 네일 몰드=몰드 & 44 & 오니코렉시스=오니코렉시스(조갑종렬증)=조갑 종렬증(오니코렉시스) \\
\hline 13 & $\begin{array}{l}\text { 네일 매트릭스=네일 매트릭스(nailmatrix)=매트릭스=조모(매트릭스)=매트릭 } \\
\text { 스(조모) }\end{array}$ & 45 & 오벌 쉐입=오발형 \\
\hline 14 & $\begin{array}{l}\text { 네일바디=네일 바디=네일 바디(조체)=조체(네일 바디)=네일 플레이트=네일 } \\
\text { 플레이트(조판)=네일 플레이트(nail plate) }\end{array}$ & 46 & 오일=큐티클 오일 \\
\hline 15 & 네일베드=네일 베드=네일 베드(조상)=조상(네일 베드) & 47 & $\begin{array}{l}\text { 오니코아트로피=위축된 네일(onychatrophia)=조갑 } \\
\text { 위축증(오니케트로피아) }\end{array}$ \\
\hline 16 & $\begin{array}{l}\text { 네일에나멜=네일 에나멜=네일 에나멜(nail enamel)=네일폴리시=에나멜=컬 } \\
\text { 러=컬러링=팔리시=폴리시=폴리쉬=유색 네일 폴리시=유색폴리시=일반 네일 } \\
\text { 폴리시=네일 컬러(nail color)=네일 컬러링 }\end{array}$ & 48 & 오렌지우드스틱=오렌지 우드스틱 \\
\hline 17 & 네일 종이 폼=네일 폼=아크릴릭 폼지 & 49 & 인조 네일=인조네일=인조팁=인조 네일=팁 \\
\hline 18 & 네일샵=네일 샵=네일 샵(shop)=네일숍=샵 & 50 & 엑티베이터=액티베이터 \\
\hline 19 & 네일 큐티클=네일 큐티클(nail cuticle)=큐티클 & 51 & 조갑비대증 $($ 오니콕시스)=조갑 비대증(오니콕시스) \\
\hline 20 & 네일 클리퍼=클리퍼 & 52 & 조갑 익상편(테리지움)=표피조막(테리지움) \\
\hline 21 & 네일 팁=네일 팁(nail tip)=인조팁=인조 팁=팁 & 53 & 젤=젤 글루 \\
\hline 22 & 네일 파일=에머리 보드=파일 & 54 & 젤 큐어링=큐어링 \\
\hline 23 & $\begin{array}{l}\text { 네일 프리에지(nail free edge)=자유연(프리에지)=프리에지=프리에지 } \\
\text { (자유연)=프리엣지=프리에지(free edge) }\end{array}$ & 55 & 큐라=큐라(cure) \\
\hline 24 & $\begin{array}{l}\text { 라이트 큐어드 젤(light cured gel)=젤=젤 네일=UV 젤=UV젤네일 } \\
=U N \text { 젤 네일=UV-젤 네일 }\end{array}$ & 56 & 탑코트=탑 코트=톱코트=탑 코트(top coat) \\
\hline 25 & 라운드 쉐입=라운드형 & 57 & 토우세퍼레이터=토우 세퍼레이터 \\
\hline 26 & 리퀴드=아크릴 리퀴드 & 58 & 프렌치=프렌치 매니큐어(French manicure)=프렌치 컬러링 \\
\hline 27 & 루눌라=루눌라(반월)=루눌라(lunula)=반월(루눌라) & 59 & 핀칭=핀칭(pinching) \\
\hline 28 & $\begin{array}{l}\text { 레귤러 매니큐어(regular manicure)=매니큐어=매니큐어(manicure) } \\
=\text { =습식매니큐어 }\end{array}$ & 60 & 페디큐어=페디큐어(pedicure) \\
\hline 29 & 리프팅=리프팅(lifting) & 61 & 하이포니키움=하조피(하이포니키움)=하이포니키움(하조피) \\
\hline 30 & 마누스=마누스(manus) & 62 & 하이 포인트=하이포인트 \\
\hline 31 & 모양(shape)=쉐입 & 63 & 헤나=헤나(henna) \\
\hline 32 & 베이스코트=베이스 코트 & & \\
\hline
\end{tabular}


까지의 회별 미용사(네일) 필기시험 문제에서 같은 의미이나 한글 표기가 다르게 된 네일 전문 용어를 분석한 결과 272 개 중 63 개로 나타났다(Table 2).

미용사(네일) 필기시험 문제에서 같은 의미의 내용이 한글 표기가 다른 경우는 네일 리무버=폴리쉬 리무버, 네일에나멜=네일 폴리시= 에나멜=컬러=컬러링=팔리시=폴리시=유색 네일 폴리시=유색 폴리 시=일반 네일 폴리시=네일 컬러링=네일 에나멜(nail enamel)=네일 컬러(nail color), 네일 종이 폼=네일 폼=아크릴릭 폼지 등 용어의 의미 는 같으나 한글표기가 다르게 되어 있는 용어들을 알 수 있었다. 이처 럼 네일 미용 용어가 의미는 같지만 다르게 표기된 경우가 많아 학습 자의 네일 미용 용어 개념 형성에 혼동이 올 수 있을 것으로 사료된다.

\section{3. 미용사(네일) 필기시험 문제에서 같은 의미의 용어가 한글 표기 띄어쓰기가 다르게 된 경우}

2014년도에 진행된 1회, 2015년 2회, 4회, 5회, 2016년 1회, 2 회까지의 회별 미용사(네일) 필기시험 문제에서 같은 의미의 용어 가 한글 표기 띄어쓰기가 다르게 된 네일 전문 용어를 분석한 결과 272 개 중 18 개로 나타났다(Table 3 ).

회별 미용사(네일) 필기시험 문제에서 같은 의미의 한글 표기 띄 어쓰기가 다르게 된 경우는 글루드라이=글루 드라이, 네일바디= 네일 바디, 네일베드=네일 베드 등 18 개로 나타났다.

\section{4. 미용사(네일) 필기시험에서 용어와 교과서 편수 자료(III)에 해당되는 용어}

교과서 편수 자료는 교육부가 검인정교과서(檢認定敎科書)를 기 술할 때 사용하도록 정한 용어로, 편수(編修)란 자료를 모아 책을 편집하고 만든다는 뜻이며, 편수용어는 넓게는 교과서를 편집하고 수정하는데 쓰이는 용어를 전부 포함하며, 교육부는 학회 - 대학 등 과 함께 심의하여 편수 용어를 규정하고 있다. 미용사(네일) 필기시 험 문제에서 추출된 272 개의 전문 용어 중에 교과서 편수 자료(II) 응용 과학 편 VII. 가사 · 실업(Ministry of Education, 2011)에 네일 미용과 관련된 용어는 총 18 개로 나타났다(Table 4).
한글 맞춤법(2014. 12. 5) 제 5 장 제4절 제 50 항에 전문 용어는 단 어별로 띄어 씀을 원칙으로 하되, 붙여 쓸 수 있다고 명시되었고, 한글 맞춤법(2014. 12. 5) 제1장 제1항, 제2항, 제 3 항에 한글 맞춤법 은 표준어를 소리대로 적고, 어법에 맞도록 함을 원칙으로 하며, 문 장의 각 단어는 띄어 쓰기를 원칙으로 한다. 외래어는 '외래어 표기 법'의 규정에 따라 적는다고 공표되었다.

이와 관련하여 Moon et al. (2013)은 개념 형성의 기초가 되는 미 용 전문 용어 사용의 적절성과 통일성 등의 문제에 대해서는 논의 되고 있지 않는 실정으로, 전문화된 학문으로서 미용교육의 발전을 위해서는 활용하는 단어나 용어의 개념이 맥락에서 적절하고 일관 성 있게 사용되어, 전문 용어를 습득할 수 있도록 용어 분석의 중요 성을 강조하였다. 그리고 Lee et al. (2012)는 미용분야의 다양한 전 문 교육이 이루어지기 위해서는 국가 수준의 교육과정에 따른 교과 서 분석에 대한 연구도 꾸준히 이루어져야 되고, 실제 교육현장에 서 제대로 활용될 수 있도록 제도적인 개선이 필요하다고 하였다.

\section{Conclusion}

본 연구에서는 2014년도에 진행된 필기 1회, 2015년 2회, 4회, 5 회, 2016 년 1 회, 2 회까지의 회별 국가기술자격의 미용사(네일) 필 기시험에 사용되는 네일 미용 전문 용어를 분석하고, 미용사(네일) 필기시험 문제에서 같은 의미의 용어이나 한글 표기가 다르게 된 경우, 미용사(네일) 필기시험 문제에서 같은 의미의 용어가 한글 표 기 띄어쓰기가 다르게 된 경우, 미용사(네일) 필기시험에서 용어 와 교과서 편수 자료(II) 응용 과학 편 VII. 가사 - 실업(Ministry of Education, 2011)에 해당되는 용어를 분석하였다.

그 결과를 살펴보면 미용사(네일) 필기시험 문제에서 네일 미용 과 관련된 네일 개론과 네일 미용기술 중 외래어로 된 네일 미용 전 문 용어를 분석한 결과, 272 개의 네일 미용 전문 용어가 분석되었 고, 추출된 272 개의 전문 용어 중에 미용사(네일) 필기시험 문제에 서 같은 의미이나 한글 표기가 다르게 된 용어는 63 개로 분석되었

Table 3. Terminology with the same meaning but different spacing in Korean in the written examination for nail technicians

\begin{tabular}{lllll}
\hline & & Written examination terminology & 스마일라인=스마일 라인 \\
2 & 글루드라이=글루 드라이 & 10 & 아크릴파우더=아크릴 파우더 \\
3 & 네일루바드=네네일 바디 루트 & 11 & 오렌지우드스틱=오렌지 우드스틱 \\
4 & 네일베드=네일 베드 & 12 & 자연네일=자연 네일 \\
5 & 네일에나멜=네일 에나멜 & 13 & 조갑비대증(오니콕시스)=조갑 비대증(오니콕시스) \\
6 & 네일샵=네일 샵 & 14 & 15 & 탑코트=탑 코트 \\
7 & 인조팁=인조 팁 & 16 & 토우세퍼레이터=토우 세퍼레이터 \\
8 & 인조네일=인조 네일 & 17 & 하이포인트=하이 포인트 \\
9 & 베이스코트=베이스 코트 & 18 & UV젤네일=UV 젤 네일 \\
\hline
\end{tabular}


으며, 같은 의미의 용어가 한글 표기 띄어쓰기가 다르게 된 용어는 18 개로 분석되었다. 그리고 272 개 중 교과서 편수 자료(II) 응용 과학 편 VII. 가사 · 실업에서 해당되는 네일 미용 전문 용어는 18 개로 분석되었 다. 그 외 한글과 외래어를 혼용하여 사용하고 있었고, 외래어가 차지 하는 비중이 높은 반면 영문 표기가 되어 있지 않는 등, 네일 전문 용 어의 통일성 및 적절성의 문제점과 네일 전문 용어 중 외래어 사용 비 중이 높음에 따라 외래어 네일 전문 용어에 대한 문제점이 나타났다.

본 연구의 결과에서 나타난 것처럼 네일 미용 전문 용어의 표기가 정확하지 않을 경우 학습자에 따른 네일 미용 용어 개념에 혼돈이 올 수 있는 문제점이 나타날 수 있으므로, 현재 사용하고 있는 네일 미용 전문 용어에 대한 체계화가 필요하다.

이러한 문제의 해결방안으로 네일 미용 국가기술자격 용어 정리를 위해 문헌고찰과 학교, 학회, 그리고 네일산업체의 실무전문가 등과 함께 심의하고, 국가기술자격 미용사(네일) 자격내용을 수정 · 보완하 여 네일 미용 전문 용어에 대한 올바른 표기로, 학습자와 현장에서 의 혼돈이 없도록 모색하여야 할 것이다.

따라서 미용사(네일) 국가기술자격 필기시험에 사용되는 네일 미용 전문 용어와 관련하여 같은 의미의 용어가 서로 다르게 표기 되는 용어, 띄어쓰기, 외래어 사용 실태와 외래어 표기 등에 대한 다양한 분석 연구로 전문 용어를 재정립하고 추후 체계화된 용어 정리의 표준화가 이루어져 네일 미용분야의 전문 용어 기틀을 마 련해야 할 것이다.

\section{References}

Cha EJ, Ahn HS. Comparison of beautician national licensing system in Germany, United Kingdom, and South Korea. Asian Journal of Beauty and Cosmetology, 9: 141-151, 2011.

Cho JY, Park JS, Kim HS. The Korean technology qualification system: new directions towards the 21 st century. The Journal of Training and Development, 6: 91-120, 1999.

Choi SM, Kim EH. The current beauty national qualifications system and test for the estheticians satisfaction. Asian Journal of Beauty and Cosmetology, 8: 289-299, 2010.

Huh EO, Whang WK, Jung YS. A study on required hours of education to reinforce the eligibility for the national certificate for estheticians. Asian Journal of Beauty and Cosmetology, 11: 547-554, 2013.

Human Resources Development Service of Korea. National technical qualification statistical yearbook 2016. Human Resources Development Service of Korea, Ulsan, pp212213, 2016.

Jeong SH. A comparative study and improvement devices on the national and international beauty therapy

Table 4. Different Korean orthography between the written examination for nail technicians and material for editing of textbooks (III)

\begin{tabular}{|c|c|c|}
\hline & $\begin{array}{l}\text { Material for editing of textbooks (III): applied science } \\
\text { (terminology/original language) }\end{array}$ & $\begin{array}{l}\text { Nail art terminology in the written examination for hairdresser } \\
\text { (nail art) }\end{array}$ \\
\hline \multirow{2}{*}{$\neg$} & 그러데이션/gradation & 그라데이션 \\
\hline & 글루 드라이/glue dry & 글루드라이 \\
\hline\llcorner & 네일아티스트/nail artist & 네일 아티스트 \\
\hline \multirow{2}{*}{ 口 } & 매니큐어/manicure & $\begin{array}{l}\text { 레귤러 메니큐어(regular manicure), 매니큐어, 매니큐어(manicure), 메니큐어, } \\
\text { 습식매니큐어, 일반 매니큐어 }\end{array}$ \\
\hline & 매트릭스/matrix & $\begin{array}{l}\text { 네일 메트릭스, 네일 매트릭스(nail matrix), 조모(매트릭스), 매트릭스, 매트릭스(조모), } \\
\text { 메트릭스 }\end{array}$ \\
\hline \multirow{4}{*}{$\circ$} & 아미노산 & 아미노산 \\
\hline & 아세테이트/acetate & 아세테이트 \\
\hline & 아크릴 네일/acrylic nail & $\begin{array}{l}\text { 스컬프처네일, 아크릴, 아크릴 네일, 아크릴릭, 아크릴릭(acrylic), 아크릴릭네일, } \\
\text { 아크릴릭 네일, 아크릴릭 스캅쳐, 원톤 스캅춰, 원톤 스컬프쳐 }\end{array}$ \\
\hline & 인조 손톱/artificial nail & 네일팁, 네일 팁, 네일팁(nail tip), 인조네일, 인조 네일, 인조팁, 인조 팁, 커브팁, 팁 \\
\hline \multirow{2}{*}{$\pi$} & 조갑/nails & 네일=자연네일 \\
\hline & 젤/gel & 젤 \\
\hline \multirow{7}{*}{ F } & 케라틴/keratin & 케라틴 \\
\hline & 컨벡스/convex & 컨벡스 \\
\hline & 컨케이브/concave & 컨케이브 \\
\hline & 칼슘/calcium(Ca) & 칼슘 \\
\hline & 컬러링/coloring & 네일에나멜, 네일 팔리쉬, 네일폴리시, 네일 폴리시, 에나멜, 컬러, 컬러링, 팔리쉬, 폴리시 \\
\hline & 큐티클/cuticle & 네일 큐티클, 네일 큐티클(nail cuticle), 큐티클 \\
\hline & 클리퍼/clipper & 클리퍼 \\
\hline
\end{tabular}


qualification. Journal of Investigative Cosmetology, 8: 6773, 2012.

Kim JH, Lee SD, Cho SY, Do SH. A study on the adoption and translation of foreign aesthetic terms into Korean. Journal of the Korea Beauty Design Society, 6: 23-29, 2010.

Lee JH, Youn CS. A study of improvements on skin (beauty) national qualification certificates system and its problems. Journal of Beauty Industry, 4: 5-28, 2010.

Lee JY, Jeun YS, Lee SY. Analysis of skin care textbooks for high schools. Asian Journal of Beauty and Cosmetology, 10: 163-171, 2012.

Lee JY, Kim MS, Kim YT. The study to improve the licence system of Korean hairdresser. Journal of the Korean Society of Cosmetology, 7: 23-30, 2001.

Lee SY, Lee MC, Cho MJ, Kim EY. Nail technician written examination. Kwangmoonkag, Paju, pp7-10, 2015.
Lim EH, Hwang JY, Kim HJ. Legislation improvement measures for national technical qualifications for cosmetology. Asian Journal of Beauty and Cosmetology, 11: 10331041, 2013.

Ministry of Education. Material for editing of textbooks ( III): applied science. Ministry of Education, Sejong, pp709798, 2011.

Moon HJ, Yoo YJ, Kim MK, Jang HH. Analysis on the status of using technical terms in specialized high schools' hair care textbooks. Asian Journal of Beauty and Cosmetology, 11: 459-463, 2013.

Oh GS. The activation plan of beauty managers-centered beauty tourism. Journal of the Korean Society of Design Culture, 17: 319-335, 2011. 


\section{국문초록}

\section{미용사(네일) 국가기술자격 필기시험의 네일 전문 용어 분석}

조미자

중부대학교 뷰티산업학부, 충청남도 금산군, 한국

목적: 본 연구는 미용사(네일) 국가기술자격 필기시험 주요항목 중 네일 개론과 네일 미용기술에서 외래어로 된 네일 전문 용어를 분 석하고 문제점을 파악하여 네일 미용 관련 전문교육기관과 산업현장에서의 원활한 용어 표기로, 미용사(네일) 국가기술자격 전문 용어 의 개선방향을 모색하고자 한다. 방법: 미용사(네일) 국가기술자격 필기시험 중, 네일 개론과 네일 미용기술에서 외래어로 된 네일 전 문 용어를 분석하고, 같은 의미의 용어 중 한글 표기가 다르게 된 경우와 띄어쓰기가 다르게 된 경우를 분석하였다. 그리고 미용사(네 일) 필기시험에서 나타난 용어와 교과서 편수 자료(II) 응용 과학 편 중 VII. 가사 · 실업에서 해당되는 네일 미용 전문 용어를 비교 분석 하였다. 결과: 네일 전문 용어를 분석한 결과 272 개의 용어가 추출되었으며, 같은 의미이나 한글 표기가 다르게 표기된 용어는 272 개 중 63 개로 나타났고, 같은 의미의 용어가 한글 표기 띄어쓰기가 다르게 표기된 용어는 272 개 중 18 개로 나타났다. 그리고 미용사 (네일) 필기시험 문제에서 추출된 용어 중 교과서 편수 자료(II)에 해당되는 용어는 18 개로 나타났다. 결론: 미용사(네일) 국가기술자 격 필기시험에 사용되는 네일 전문 용어와 관련하여 같은 의미의 용어가 서로 다르게 표기되는 용어, 띄어쓰기, 외래어 표기 등에 대한 다양한 분석 연구로, 추후 체계화된 용어 정리의 표준화가 이루어져 할 것이다.

핵심어: 미용사(네일), 국가기술자격, 네일 미용, 전문 용어, 필기시험

\section{참고문헌}

교육부. 교과서 편수 자료(III): 응용 과학 편. 교육부, 세종, pp709-798, 2011.

김재현, 이순덕, 조승연, 도수환. 미용향장 용어의 한글화 구축 시도. 코리아뷰티디자인학회지, 6: 23-29, 2010.

문혜진, 유유정, 김미경, 장현희. 특성화 고등학교 헤어 미용 교과서의 전문용어 분석. 아시안뷰티화장품학술지, $11: 459-$ 463, 2013.

오강수. 미용경영자 중심의 미용관광 활성화 방안. 한국디자인문화학회지, 17: 319-335, 2011.

이서윤, 이미춘, 조미자, 김은영. 미용사 네일 필기시험: 한 권으로 합격하기. 광문각, 파주, $\mathrm{pp} 7-10,2015$.

이자영, 전연숙, 이순영. 고등학교 피부관리 교과서 분석. 아시안뷰티화장품학술지, 10: 163-171, 2012.

이주영, 김미선, 김영태. 한국미용사 자격증 제도의 개선에 관한 연구. 한국미용학회지, 7: 23-30, 2001.

이지현, 윤천성. 피부(미용) 국가자격증 제도 및 문제점에 대한 개선방안 연구. 뷰티산업연구, 4: 5-28, 2010.

임은화, 황지영, 김현정. 미용사 국가기술자격제도 법제화의 개선 방안. 아시안뷰티화장품학술지, 11: 1033-1041, 2013.

정선희. 미용사(피부) 국가자격증과 국제자격증 $\mathrm{CIDESCO}$ - ITEC의 비교 분석 및 개선방안. 대한미용학회지, 8: 67-73,

2012.

조정윤, 박종성, 김현수. 21세기를 향한 국가기술자격제도의 발전방안 연구. 산업교육연구, 6: 91-120, 1999.

차의진, 안홍석. 한국과 독일 및 영국의 피부미용사 국가자격증 제도의 비교연구. 아시안뷰티화장품학술지, 9: 141-151,

2011.

최성미, 김은화. 현행 피부미용 국가자격제도 및 시험에 대한 피부미용사의 만족도. 아시안뷰티화장품학술지, 8: 289-299, 2010. 한국산업인력공단. 2016 국가기술자격통계연보. 한국산업인력공단, 울산, pp212-213, 2016.

허은옥, 황완균, 정연선. 피부미용사 국가자격증 지원요건 강화를 위한 필수교육시간 연구. 아시안뷰티화장품학술지, $11:$

$547-554,2013$. 


\section{中文摘要}

\section{指甲美容师国家技术资格书面考试中的美甲术语分析}

趙美子

中部大學美容扮裝學科, 忠淸南道錦山郡，韩国

目的: 分析指甲美容师国家技术资格书面考试主要项目中美甲概论和美甲美容技术中出现的美甲术语外来词, 掌握了美甲术 语的问题，在美甲相关培训机构和产业领域中为更好地应用术语的正字法，探索指甲美容师国家技术资格专门术语的改善方案。 方法: 分析指甲美容师国家技术资格书面考试主要项目中美甲概论和美甲美容技术中出现的美甲术语外来词，并分析相同意 义的术语不同的韩国语表示以及相同意义的术语不同的韩国语间距以及比较分析指甲美容师国家技术资格书面考试中出现的术 语与教科书编辑的材料应用科学（III）家事·实务中的美甲术语。结果：美甲术语分析结果，出现了272个美甲术语, 其中相同 意义不同韩国语表示方法的有63个，相同意义不同韩国语间距表示的有 18 个。美甲美容师国家技术资格书面考试中出现的术 语中与教科书编辑的材料应用科学（III）相关的有 18 个。结论: 在美甲美容师国家技术资格书面考试中出现的美甲术语中, 分 析相同意义不同韩国语表示的术语、不同间距的术语以及外来语表示的术语, 表明将来需应进一步研究系统标准化的术语。

关键词：美甲师，国家技术资格，美甲，专业术语，书面考试 